Cite this: Chem. Commun., 2014 50, 2341

Received 8th November 2013, Accepted 9th January 2014

DOI: $10.1039 / c 3 c c 48538 b$

www.rsc.org/chemcomm

\section{Diastereoselective synthesis of a bicyclic $\beta$-lactam with penicillin G-like spectrum of activity by carbonylation of an acyclic diaminocarbene $\uparrow$}

\author{
Tim Schulz, ${ }^{a}$ Christian Färber, ${ }^{a}$ Michael Leibold, ${ }^{a}$ Clemens Bruhn, ${ }^{a}$ \\ Pascal Prochnow, ${ }^{b}$ Julia E. Bandow, ${ }^{b}$ Tanja Schneider, ${ }^{c}$ Timo Porsch, ${ }^{d}$ \\ Max C. Holthausen ${ }^{\star d}$ and Ulrich Siemeling ${ }^{{ }^{a}}$
}

\begin{abstract}
Diisopropylamino-cis-2,6-dimethylpiperidinocarbene reacts regioand diastereoselectively with $\mathrm{CO}$ to afford a bicyclic $\beta$-lactam with $100 \%$ atom efficiency, whose spectrum of activity resembles that of penicillin G or amoxicillin.
\end{abstract}

The chemistry of carbenes and ketenes has been intertwined for a century now. ${ }^{1}$ In 1913 Staudinger described the thermal decarbonylation of ketenes, together with an analysis of the follow-up products of the resulting transient carbenes. ${ }^{2}$ The decomposition of the parent ketene $\mathrm{H}_{2} \mathrm{C}=\mathrm{C}=\mathrm{O}$ to $\mathrm{CO}$ and $\mathrm{CH}_{2}$ is one of the most extensively studied reactions in physical chemistry. ${ }^{3}$ Conversely, a classic method for the detection of transient carbenes is their trapping by carbonylation. ${ }^{4}$

The advent of isolable N-heterocyclic carbenes in $1991^{5}$ triggered the development of these and related persistent diaminocarbenes from laboratory curiosities to reliable workhorses in synthesis and catalysis. ${ }^{6}$ Such carbenes are usually inert towards $\mathrm{CO},{ }^{7}$ but exceptions occur with particularly electrophilic representatives such as, for example, acyclic diaminocarbenes (ADACs) $1 .^{8}\left(\mathrm{iPr}_{2} \mathrm{~N}\right)_{2} \mathrm{C}$ (1a) was reported in 1996 as the first ADAC to be isolated and structurally characterised. ${ }^{9}$ We found that its primary carbonylation product $\left(\mathrm{iPr}_{2} \mathrm{~N}\right)_{2} \mathrm{C}=\mathrm{C}=\mathrm{O}$ (2a) undergoes a remarkable intramolecular follow-up reaction (Scheme 1). ${ }^{8 b, e} \mathrm{~A}$ retro-Wolff rearrangement leads to the (amino)(carboxamido)carbene 3a, which subsequently affords the $\beta$-lactam $4 a$ by a $\mathrm{C}-\mathrm{H}$ insertion. Bona fide examples of this reaction type are rare. Previously studied

\footnotetext{
${ }^{a}$ Institute of Chemistry, University of Kassel, Heinrich-Plett-Str. 40, D-34132 Kassel, Germany.E-mail: siemeling@uni-kassel.de

${ }^{b}$ Biology of Microorganisms, Ruhr University Bochum, Universitätsstr. 150, D-44801 Bochum, Germany

${ }^{c}$ Pharmaceutical Microbiology, University of Bonn, Meckenheimer Allee 168, D-53115 Bonn, Germany

${ }^{d}$ Institut für Anorganische und Analytische Chemie, Johann Wolfgang Goethe-Universität Frankfurt, Max-von-Laue-Str. 7, D-60438 Frankfurt am Main, Germany. E-mail: max.holthausen@chemie.uni-frankfurt.de

$\dagger$ Electronic supplementary information (ESI) available: Experimental, crystallographic and computational details, Fig. S1-S3 and Table S1. CCDC 951678. For ESI and crystallographic data in CIF or other electronic format see DOI: 10.1039/ c3cc $48538 \mathrm{~b}$
}

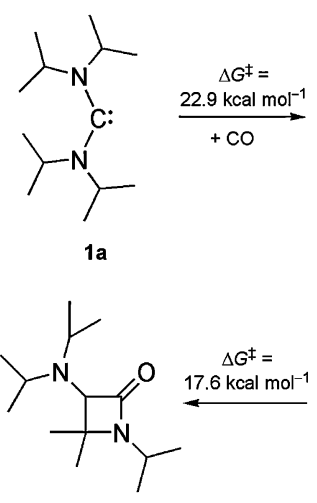

$4 a$

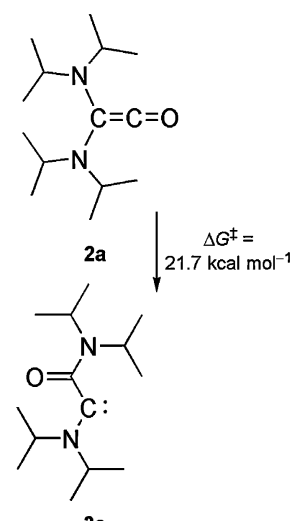

3a
Scheme 1 Carbonylation of 1a, leading to $\beta$-lactam $4 a$ (racemic mixture) as the final product. $\Delta G_{298}^{\ddagger}$ values were calculated by DFT methods.

cases exhibit considerably higher calculated activation barriers $\left(\geq 37 \mathrm{kcal} \mathrm{mol}^{-1}\right) \cdot{ }^{10}$ The reaction $\mathbf{1 a}+\mathrm{CO} \rightarrow \mathbf{4 a}$ represents a new entry to the important $\beta$-lactam ring system ${ }^{11}$ and proceeds with $100 \%$ atom efficiency. ${ }^{12}$ As a first milestone of a systematic study to probe the limitations of this new synthetic method, we have shown that $\beta$-lactam formation requires very bulky ADACs. ${ }^{8 b}$ We here address the question whether this reaction can be applied to the synthesis of bicyclic $\beta$-lactams, using bulky ADACs with cyclic amino groups. This is important in view of the bicyclic nature of the penicillins and cephalosporins, which are the most widely used $\beta$ lactam antibiotics. ${ }^{13}$ Diisopropylamino-cis-2,6-dimethylpiperidinocarbene $\left(\mathrm{iPr}_{2} \mathrm{~N}\right) \mathrm{C}\left(\mathrm{PipMe}_{2}\right)(\mathbf{1 b})^{14}$ is the only ADAC known to date which meets the requirements for this investigation. Just like 1a, it is very bulky. In addition, it contains a cyclic amino group ( $\left.\mathrm{PipMe}_{2}\right)$, which incidentally may be viewed as a conformationally constrained version of the $\mathrm{iPr}_{2} \mathrm{~N}$ group.

We have shown previously that $\mathbf{1 a}$ and $\mathbf{1 b}$ are very similar in terms of stability, both undergoing a slow $\beta$-fragmentation reaction in solution. ${ }^{15}$ Indeed, we have found such a chemical similarity also in their carbonylation. The reaction of $\mathbf{1 b}$ with $\mathrm{CO}$ proceeds smoothly and swiftly at room temperature, cleanly affording the 


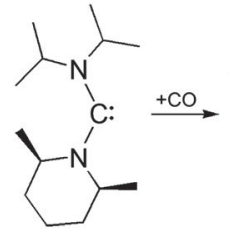

$1 \mathrm{~b}$

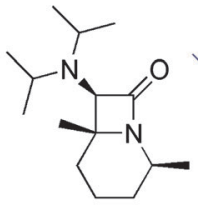

cis-4b

$(-32.5)$

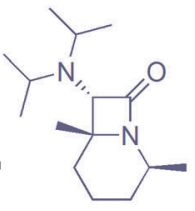

trans-4b

$(-31.8)$

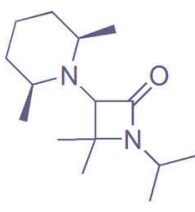

$4 c$

$(-33.3)$
Scheme 2 Carbonylation of $\mathbf{1 b}$, leading to the bicyclic $\beta$-lactam cis- $\mathbf{4 b}$ as the final product. The isomers trans-4b and $\mathbf{4 c}$ shown in grey are not observed. Only one enantiomer is shown in each case. Calculated $\Delta G_{298}$ values $\left(\mathrm{kcal} \mathrm{mol}^{-1}\right.$ ) are given in parentheses.

bicyclic $\beta$-lactam derivative cis-4b (Scheme 2). This process is regioselective, since only the $\mathrm{PipMe}_{2}$ unit undergoes the rearrangement and concomitant $\mathrm{C}-\mathrm{H}$ insertion. The monocyclic $\beta$-lactam 4c, which contains an intact PipMe $\mathrm{P}_{2}$ unit, is not observed. Equally remarkable is the diastereoselectivity of the reaction. The diastereomer of $\mathbf{4 b}$, which exhibits a trans orientation of the $\mathrm{iPr}_{2} \mathrm{~N}$ group with respect to the methyl substituents (trans-4b), is not observed.

The all-cis arrangement of the substituents at the bicyclic core of the final product is unequivocally demonstrated by the structure of the hydrochloride $[$ cis-4bH] $\mathrm{Cl}$, which we were able to determine by single-crystal X-ray diffraction (Fig. 1).

We have investigated the formation of cis-4b using high-level DFT calculations (B2GP-PLYP-D/def2-QZVP//B97-D/SVP, see $\mathrm{ESI}^{\dagger} \dagger$ for details), with special attention to the axial ( $\mathrm{ax}$ ) and the equatorial conformation (eq) of the $\mathrm{PipMe}_{2}$ group, including in our analysis also possible boat (b) conformations of the six-membered ring (Fig. 2). First of all, we address thermodynamic aspects concerning the final carbonylation product. The energy of the experimentally observed bicyclic $\beta$-lactam cis-4b is $0.7 \mathrm{kcal} \mathrm{mol}^{-1}$ lower than that of its diastereomer trans-4b and $0.8 \mathrm{kcal} \mathrm{mol}^{-1}$ higher than that of the monocyclic $\beta$-lactam 4c (Scheme 2). These small

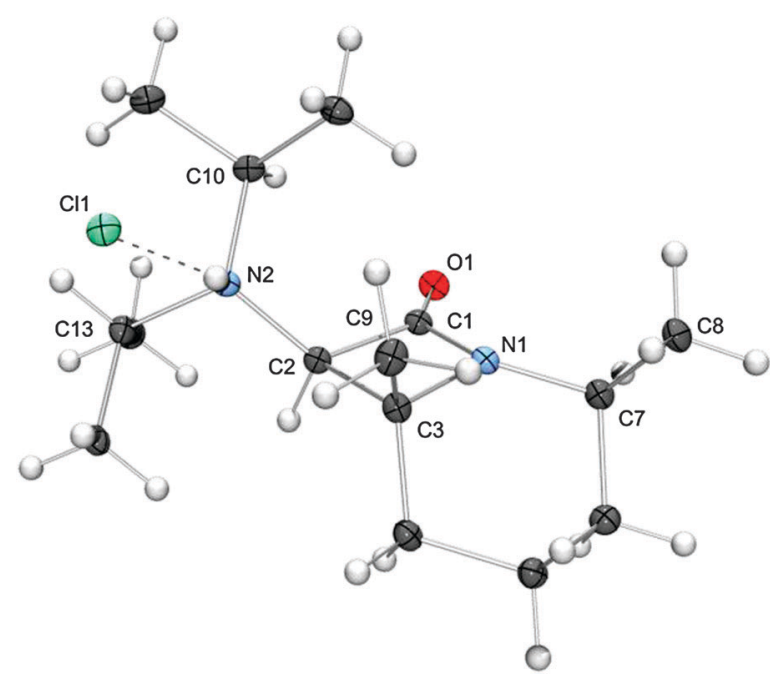

Fig. 1 Molecular structure of [cis-4bH]Cl in the crystal (ellipsoids drawn at the $30 \%$ probability level). The broken line indicates a hydrogen bond between the chloride anion and the cationic $\mathrm{iPr}_{2} \mathrm{HN}$ substituent. energy differences indicate that the intramolecular follow-up reaction of $\mathbf{2} \mathbf{b}$, which exclusively gives rise to cis-4b, is governed by kinetic, rather than thermodynamic, factors. Therefore, we now turn our attention to the course of the reaction. The axial carbene conformer $\mathbf{1 b}_{\mathrm{ax}}$ is more stable than the equatorial one $\left(\mathbf{1} \mathbf{b}_{\text {eq }}\right.$ ) by $6.8 \mathrm{kcal} \mathrm{mol}^{-1}$ (not shown in Fig. 2; see ESI $\dagger$ ). This significant contrasteric bias is due to the anomeric effect. ${ }^{16}$ It is less pronounced for the ketene $\mathbf{2} \mathbf{b}$, whose axial conformer is only $0.9 \mathrm{kcal} \mathrm{mol}^{-1}$ lower in energy than the equatorial one, which corresponds to a value of the equilibrium constant of ca. 5 at room temperature. For each calculated reaction pathway, the first step, viz. the retro-Wolff rearrangement, is ratedetermining. This rearrangement can involve either the $\mathrm{PipMe}_{2}$ or the $\operatorname{iPr}_{2} \mathrm{~N}$ group. For the dominant conformer $2 \mathbf{b}_{\mathrm{ax}}$ the activation barrier has a value of $21.3 \mathrm{kcal} \mathrm{mol}^{-1}$ for the process which involves the $\mathrm{PipMe}_{2}$ group, leading to the transient carbene $\mathbf{3} \mathbf{b}_{\mathrm{ax}}$. The corresponding process which involves the $\mathrm{iPr}_{2} \mathrm{~N}$ group and would finally lead to $\mathbf{4 c}$ has a significantly higher barrier $\left(\Delta G^{\ddagger}=25.6 \mathrm{kcal} \mathrm{mol}^{-1}\right.$, see $\mathrm{ESI} \dagger$ for details). In the case of the less abundant conformer $\mathbf{2} \mathbf{b}_{\mathrm{eq}}$ too, the retro-Wolff rearrangement involving the $\mathrm{PipMe}_{2}$ unit is kinetically favoured over the alternative process involving the $\operatorname{iPr}_{2} \mathrm{~N}$ group $\left(\Delta G^{\ddagger}=20.1\right.$ vs. $\left.23.7 \mathrm{kcal} \mathrm{mol}^{-1}\right)$. For both ketene conformers the activation energy differences $\left(\Delta \Delta G^{\ddagger}=4.3 \mathrm{kcal} \mathrm{mol}^{-1}\right.$ and $3.6 \mathrm{kcal} \mathrm{mol}^{-1}$ for $\mathbf{2 \mathbf { b } _ { \mathrm { ax } }}$ and $\mathbf{2} \mathbf{b}_{\text {eq }}$, respectively) are sufficiently large to be compatible with an essentially exclusive formation of cis-4b via the kinetically favoured carbene $\mathbf{3 b}$. At the same time, the energy barrier differences for the various calculated pathways are small enough to suggest that subtle changes in the periphery of a bulky ADAC may have a dramatic influence on the outcome of its carbonylation. A comprehensive study will be required to develop a rationale for the reactivity of the primary carbonylation product, viz. the diaminoketene 2 .

We have investigated the antimicrobial activity of the monocyclic $\beta$-lactam $\mathbf{4 a}$ and its bicyclic relative cis-4b against Gram-positive and Gram-negative bacteria by determining their minimal inhibitory concentrations (MICs) (see ESI $\dagger$ ). The bicyclic $\beta$-lactam cis-4b exhibits significant activity against the Gram-positive bacteria B. subtilis and $S$. aureus. MIC values are $64-128 \mu \mathrm{g} \mathrm{mL} \mathrm{mL}^{-1}$ for the $S$. aureus type strain and $128 \mu \mathrm{g} \mathrm{mL}^{-1}$ for B. subtilis 168 and a methicillin-resistant $S$. aureus (MRSA) strain. The antibiotic activity of $4 \mathbf{a}$ is lower by a factor of $2\left(\mathrm{MIC}=256 \mu \mathrm{g} \mathrm{mL} \mathrm{m}^{-1}\right.$ in all cases). Both compounds are inactive against Gram-negative bacteria. Their spectrum of activity resembles that of penicillin $\mathrm{G}$ or amoxicillin, whose activities, however, are higher than that of $c i s-\mathbf{4 b}$ by $c a$. two orders of magnitude.

In conclusion, the efficient and highly selective synthesis of cis-4b from $\mathbf{1 b}$ and CO under mild conditions opens up new possibilities to access unprecedented bicyclic $\beta$-lactams with useful antibiotic properties. We will continue our study with new ADACs containing bulky cyclic amino substituents, which we are currently developing.

We thank the DFG for generous funding (grant SI 429/19-1). T. S. is grateful to the Studienstiftung des deutschen Volkes for a doctoral fellowship. J. E. B. and P. P. are financially supported by a grant from the German federal state of North Rhine-Westphalia and the European Union (European Regional Development Fund, 

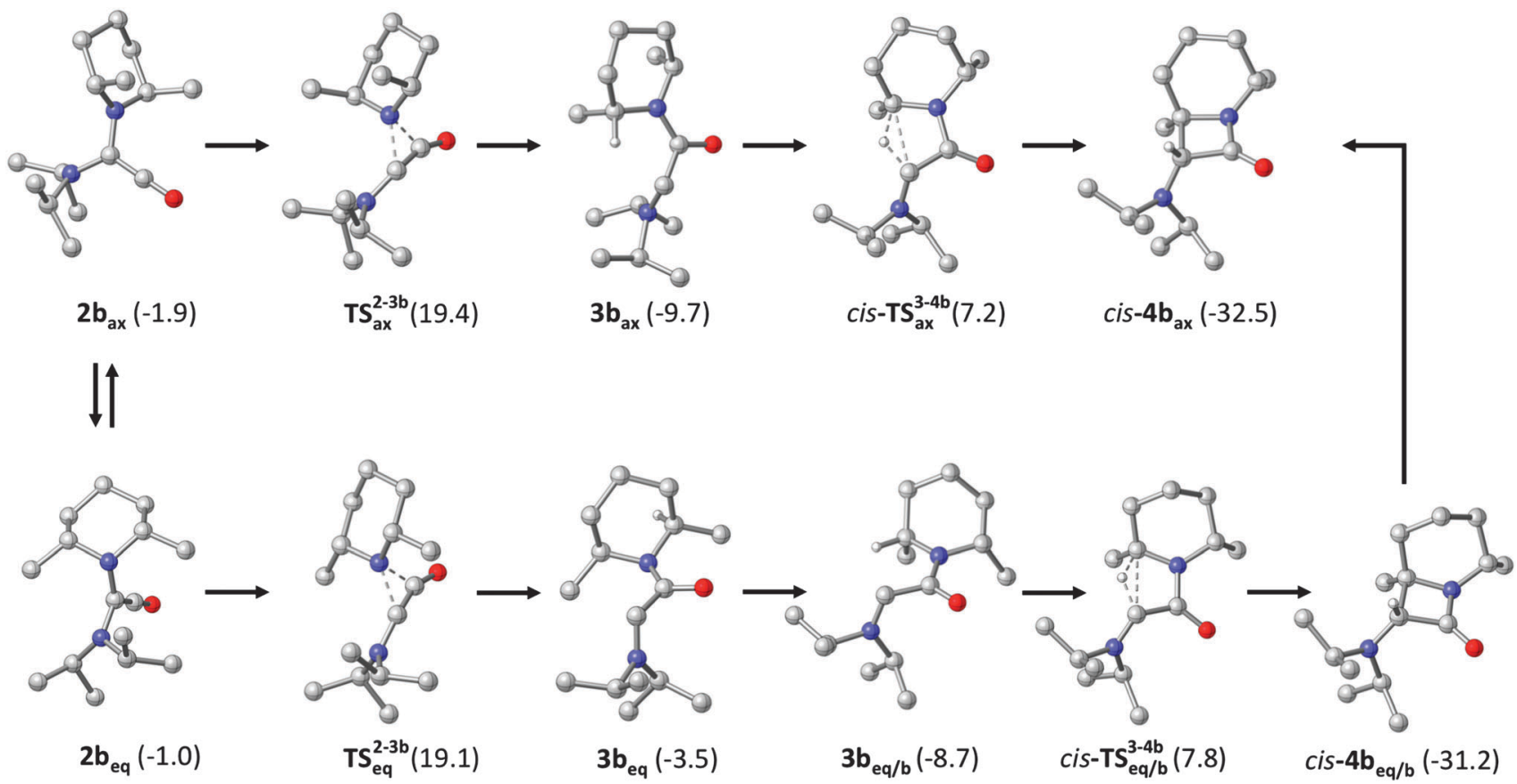

Fig. 2 Computed kinetically favourable reaction pathways for diaminoketene $\mathbf{2 b}$ (shown for one enantiomer only). Pathways potentially leading to trans-4b and $\mathbf{4 c}$ (Scheme 2) are kinetically less favourable and have been omitted for clarity (see ESI $\dagger$ for details). $\$$

Investing in your future). Quantum-chemical calculations were performed at the Center for Scientific Computing (CSC) Frankfurt on the LOEWE-CSC high-performance computing cluster.

\section{Notes and references}

$\$$ In the same vein, the nucleophilic addition of $\mathbf{1 b}$ to $\mathbf{2 b}$, affording the oxyallyl species $(\mathbf{1 b})_{2} \mathrm{CO}$, turned out to be kinetically unfavourable and has therefore not been incorporated in Fig. S2 (see ESI $\dagger$ for details).

1 (a) A. D. Allen and T. T. Tidwell, Chem. Rev., 2013, 113, 7287; (b) A. D. Allen and T. T. Tidwell, Eur. J. Org. Chem., 2012, 1081; (c) T. T. Tidwell, Ketenes, Wiley, Hoboken, 2nd edn., 2006.

2 H. Staudinger and R. Endle, Ber. Dtsch. Chem. Ges., 1913, 46, 1437.

3 (a) H. Xiao, S. Maeda and K. Morokuma, J. Phys. Chem. A, 2013, 117, 7001;

(b) Y. Ogihara, T. Yamamoto and S. Kato, J. Phys. Chem. A, 2010, 114, 9981; (c) A. L. Kaledin, J. Seong and K. Morokuma, J. Phys. Chem. A, 2001, 105, 2731; (d) C. G. Morgan, M. Drabbels and A. M. Wodtke, J. Phys. Chem., 1996, 105, 4550; (e) K. Knox, R. G. W. Norrish and G. Porter, J. Chem. Soc., 1952, 1477; $(f)$ W. F. Ross and G. B. Kistiakowski, J. Am. Chem. Soc., 1934, 56, 1112; $(g)$ R. W. G. Norrish, H. G. Crone and O. Saltmarsh, J. Chem. Soc., 1933, 1533.

4 (a) S. C. Reed, G. J. Capitosti, Z. Zhu and D. A. Modarelli, J. Org. Chem., 2011, 66, 287; (b) W. Sander, R. Hübert, E. Kraka, J. Gräfenstein and D. Cremer, Chem.-Eur. J., 2000, 6, 4567; (c) P. Visser, R. Zuhse, M. W. Wong and C. Wentrup, J. Am. Chem. Soc., 1996, 118, 12598; (d) J. R. Ammann, R. Subramanian and R. S. Sheridan, J. Am. Chem. Soc., 1992, 114, 7592; (e) W. W. Sander, J. Org. Chem., 1988, 53, 121; $(f)$ M. S. Baird, I. R. Dunkin, N. Hacker, M. Poliakoff and J. J. Turner, J. Am. Chem. Soc., 1981, 103, 5190.

5 A. J. Arduengo III, R. L. Harlow and M. Kline, J. Am. Chem. Soc., 1991, 113, 361.

6 (a) M. Fèvre, J. Pinaud, Y. Gnanou, J. Vignolle and D. Taton, Chem. Soc. Rev., 2013, 42, 2142; (b) in N-Heterocyclic Carbenes, ed. S. DíezGonzález, RSC, Cambridge, 2011; (c) T. Dröge and F. Glorius, Angew. Chem., Int. Ed., 2010, 49, 6940; (d) J. Vignolle, X. Cattoën and D. Bourissou, Chem. Rev., 2009, 109, 3333; (e) F. E. Hahn and M. C. Jahnke, Angew. Chem., Int. Ed., 2008, 47, 3122; $(f)$ D. Enders, O. Niemeier and A. Henseler, Chem. Rev., 2007, 107, 5606.

7 D. Martin, M. Soleilhavoup and G. Bertrand, Chem. Sci., 2011, 2, 389. 8 (a) D. Martin, C. E. Moore, A. L. Rheingold and G. Bertrand, Angew. Chem., Int. Ed., 2013, 52, 7014; (b) T. Schulz, C. Färber, M. Leibold, C. Bruhn, W. Baumann, D. Selent, T. Porsch, M. C. Holthausen and U. Siemeling, Chem. Commun., 2013, 49, 6834; (c) U. Siemeling, Aust. J. Chem., 2011, 64, 1109; (d) C. Goedecke, M. Leibold, U. Siemeling and G. Frenking, J. Am. Chem. Soc., 2011, 133, 3557; (e) U. Siemeling, C. Färber, C. Bruhn, M. Leibold, D. Selent, W. Baumann, M. von Hopffgarten, C. Goedecke and G. Frenking, Chem. Sci., 2010, 1, 697.

9 R. W. Alder, P. R. Allen, M. Murray and A. G. Orpen, Angew. Chem., Int. Ed. Engl., 1996, 35, 1121.

10 (a) C. Wentrup, H. Bibas, A. Kuhn, U. Mitschke and M. C. MsMills, J. Org. Chem., 2013, 78, 10705; (b) G. G. Qiao, W. Meutermans, M. W. Wong, M. Träubel and C. Wentrup, J. Am. Chem. Soc., 1996, 118, 3852; $(c)$ M. T. Nguyen, M. R. Hajnal and L. G. Vanquickenborne, J. Chem. Soc., Perkin Trans. 2, 1994, 169; (d) M. T. Nguyen, M. R. Hajnal, T.-K. Ha, L. G. Vanquickenborne and C. Wentrup, J. Am. Chem. Soc., 1992, 114, 4387.

11 (a) B-Lactams: Unique Structures of Distinction for Novel Molecules, Top. Heterocycl. Chem., ed. B. K. Banik, Springer, Berlin, 2013, vol. 30; (b) Heterocyclic Scaffolds I: $\beta$-Lactams, Top. Heterocycl. Chem., ed. B. K. Banik, Springer, Berlin, 2010, vol. 22; (c) T. T. Tidwell, Angew. Chem., Int. Ed., 2008, 47, 1016.

12 (a) R. A. Sheldon, Pure Appl. Chem., 2000, 72, 1233; (b) B. M. Trost, Angew. Chem., Int. Ed. Engl., 1995, 34, 259; (c) B. M. Trost, Science, 1991, 254, 1471.

13 (a) J. F. Fisher, S. O. Meroueh and S. Mobashery, Chem. Rev., 2005, 105, 395; (b) R. P. Elander, Appl. Microbiol. Biotechnol., 2003, 61, 385.

14 G. D. Frey and W. A. Herrmann, J. Organomet. Chem., 2005, 690, 5876.

15 T. Schulz, M. Leibold, C. Färber, M. Maurer, T. Porsch, M. C. Holthausen and U. Siemeling, Chem. Commun., 2012, 48, 9123.

16 E. V. Anslyn and D. A. Dougherty, Modern Physical Organic Chemistry, University Science Books, Sausalito, 2006, p. 123. 